\title{
Imnografia, geometria și arhitectura bizantină. O hermeneutică teologică inedită, pe marginea unui tropar fotian
}

\author{
Claudiu Ioan COMAN *
}

Abstract: Hymnography, geometry and Byzantine architecture. An original theological hermeneutics, on the edge of a Photian troparion. In this study I tried to draw the principal lines of the symbiosis between the byzantine eclesiastical architecture and a fotian tropar. The idea I develop is that the eclesial space has an important rol in the theological thinking along with iconography. The possibility on an obvious connection between the fotian immunography and architecture remaines a current issue wich must be extended in further research.

Keywords: Fotius, ecclesiastical architecture, geometry, hymnography.

Studiul pe care îl propun celor interesați are în vedere în special „consecințele” matematice ale gândirii fotiene. Prefer să încep demersul argumentativ în sens invers: din contemporaneitate către perioada teologiei bizantine, pe care o consider bipolară. Ea este atât de sorginte biblică, cât și iconologică. Avem deja două argumente forte pe care le voi considera elementele de bază pentru ideile pe care îmi propun să le dezvolt. Dar, până acolo, important este un eseu al profesorului şi academicianului Mircea Dumitru, intitulat Formă și necesitate ${ }^{1}$.

\footnotetext{
* Absolvent al cursurilor de Master în Teologie Biblică, Facultatea de Teologie Ortodoxă „Dumitru Stăniloae” din Iaşi, preot paroh al bisericii „Sf. Ierarh Nicolae" din Ioneasa (jud. Suceava).

${ }^{1}$ Mircea Dumitru, Lumi ale gândirii. Zece eseuri logico-metafizice, cuvânt înainte de Andrei Pleșu, Iaşi, Edit. Polirom, 2019, p. 15-24.
} 
Argumentându-și ideile pe baza Tractatus-ului lui Wittgenstein, profesorul Dumitru afirmă că ,ideea unei forme propoziționale este un ingredient esențial în acea parte din Tractatus care ne oferă conexiunea dintre limbaj și realitate"2. Aprofundând problema, eseul demonstrează că „,eea ce face ca separarea dintre lume și limbaj să fie depășită și unificată, în felul acesta conferindu-i limbajului rolul de mijloc de reprezentare a stărilor de lucruri, este această «formă comună» a limbajului și a faptelor"3.

De reținut este un singur aspect din argumentaţie, anume „forma comună a limbajului și a faptelor”. $\mathrm{Cu}$ alte cuvinte, ceea ce ne transmite textul citat este faptul că realul, domeniul empiricului, devine unitar atunci când părțile componente sunt reunite și analizate ca un întreg, care ia forma unei așa-numite ,propoziții moleculare" despre care, iarăşi, profesorul Dumitru spune că ,are o analiză completă unică, ceea ce relevă faptul că propoziţia compusă este o funcţie de adevăr de anumite propoziții atomare care oglindesc stările de lucruri existente" 4 .

Afirmațiile de mai sus pot fi înțelese și atunci când, de exemplu, le supunem unui alt tip de analiză: cea „spațială”. Suntem deja într-un domeniu interesant, cel al arhitecturii care „zidește" sufletește. Din perspectivă biblică e vorba despre importanța și, implicit, despre hermeneutica pietrei celei din capul unghiului (cf. Ps. 117, 22). În continuare mă voi strădui să arăt de ce este atât de important textul poetic pentru studiul nostru.

Exegetul Allen P. Ross afirmă că odată cu psalmul 117 (118) se încheie grupul de cântece al Hallel-ului; așadar există posibilitatea ca textul psalmului să fi fost scris pentru Sărbătoarea Corturilor, poate chiar cu ocazia primei Sărbători a Corturilor, atunci când poporul s-a întors din exil ${ }^{5}$. Argumentaţia lui Ross

\section{${ }^{2}$ Ibidem, p. 16.}

${ }^{3}$ Ibidem, p. 17.

${ }^{4}$ Ibidem.

${ }^{5}$ Allen P. Ross, „Psalmii”, în: John F. Walvoord, Roy B. Zuck, Comentariu al Vechiului Testament. O expunere a Scripturilor făcută de profesorii de la 
vizează și un alt aspect important, acela că ,psalmistul a arătat cum Domnul a triumfat asupra tuturor popoarelor care înconjurau Israelul". Apoi, Ross merge cu argumente mai departe și, aspect esențial pentru tema de faţă, spune că este posibil ca ,imaginea pietrei să fie inspirată din construcția Templului din perioada postexilică" 7 .

Cele trei tematici creionate mai sus reprezintă elementele pe care, în cele ce urmează, îmi propun să le dezvolt, anume: de la „forma comună a limbajului și a faptelor”, cu ajutorul unui element de legătură, care ar putea fi reprezentat de aşa-numitele „propoziţii compuse”, să ajungem la „oglindirea stărilor de lucruri existente" care denotă ideea de spațiu. Fapt este că elementele enumerate sunt convergente și pot fi înțelese în mai multe feluri, unul dintre acestea, pe care mă voi concentra în cele ce urmează, este arhitectura ziditoare, înțeleasă ca ,adevărata piatră din capul unghiului".

Dar, de ce consider că este nevoie, în situația de față, de un dublu înțeles, spațial și arhitectonic? Din capul locului, ceea ce miam propus nu a fost nicidecum o forțare a argumentării, care să servească neapărat ipotezelor mele. Însă, aici, avem un element de legătură care abia dacă este sesizat și care unește cele trei elemente/planuri de mai sus, anume: simbolismul mereu actual al întoarcerii din exil despre care vorbea hermeneutica operată de Ross. Punctul forte aici este, deci, intoarcerea. Voi apela, pentru clarificare, la ceea ce am putea numi ,istoria penitenței”. Importante, și în această situație, mi se par a fi două studii ale unor specialiști în domeniu care ne-ar propulsa înspre ideile de bază ale epocii fotiene pe care o am în vizor.

Voi începe cu studiul unui specialist în Istoria creștinismului timpuriu, profesor de teologie bizantină la Universitatea Notre Dame, Alexis Torrance. Într-un important volum, dedicat cercetării aspectelor penitențiale în ceea ce numim a fi Antichitatea târzie,

Seminarul Teologic Dallas, trad. Octavian Verlan și Constantin Leontiuc, Edit.

Fundației E.B.E., 2010, p. 874.

${ }^{6}$ Ibidem.

${ }^{7}$ Ibidem. 
Torrance, spre finalul cercetării întreprinse, face următoarea afirmație: ,pentru studiul suplimentar [al pocăinței - n. n.] o a doua chestiune este cea a influenței conceptelor monahale de pocăință asupra populației din imperiu. Sugestia a fost făcută într-un mod preliminar când s-a menționat că idealurile monahale și instituționale de pocăință au fost de timpuriu integrate și manifestate în imperiu, în special prin propovăduirea populară a lui Ioan Gură de Aur [...] Ne-ar fi însă de ajutor să cercetăm și alte surse. De exemplu, locul pocăinţei în abundentele colecții de ostrace și papirusuri egiptene din această perioadă ar merita să fie analizate în acest context [...] De asemenea, dimensiunea penitenţială a Liturghiei artei și arhitecturii bisericești s-ar putea dovedi folositoare pentru răspunsuri. Un exemplu frapant de pocăință în artă se găsește în mozaicul din narthexul Sfintei Sofia. Un studiu minuțios al lui Oikonomides leagă mozaicul - care-L zugrăvește pe Hristos așezat, flancat de medalioane cu Fecioara Maria și Arhanghelul Mihail și un împărat care se pocăiește, închinându-se la picioarele lui Hristos - de episodul celei de-a patra căsătorii a lui Leon al VI-lea (866-912), pentru care a fost mustrat aspru de autoritățile bisericești. Imaginea care sugerează ideea unei pocăințe neîncetate încă de la intrarea în biserică, pare să fi fost realizată la dorința lui Leon însuși"8.

Am optat pentru acest citat amplu din studiul lui Torrance, pentru că aici sunt prezentate alte aspecte care ne conduc spre epoca sfântului patriarh Fotie și, implicit, spre gândirea acestuia. Torrance îşi începe argumentarea pornind de la celebrele comunităţi monahale, către impactul cu viața cotidiană a populației din imperiu, implicând, după cum am observat, „dimensiunea penitenţială a artei și a arhitecturii perioadei respective”. Însă, pentru trasarea liniilor unei perspective corecte asupra tematicii, curiozitatea m-a făcut să verific dacă există precedente la opinia lui Torrance, sau dacă, dimpotrivă, studiul său de dată recentă este deschizător de drumuri în această arie a cercetării.

${ }^{8}$ Alexis TorRance, Pocăința în Antichitatea târzie. Asceza la Părinții răsăriteni și organizarea vieții creștine (cca 400-650 d. Hr), trad. Dragoș Dâscă, Iaşi, Edit. Doxologia, 2014, p. 258-260. 
În acest sens, de pildă, studiul lui Uwe Michael Lang dovedește că dimensiunea penitențială și orientarea în timpul rugăciunii sunt în armonie. Lang se folosește de un argument patristic excelent: apelează la scrierile lui Ioan Damaschin care oferă o explicație lucidă a orientării din timpul rugăciunii creștine tocmai ca o concluzie la monumentala sa lucrare De Fide Orthodoxa. Iată cuvintele acestuia:

„Nu întâmplător, nici la nimereală ne închinăm spre răsărit, ci, întrucât suntem alcătuiți din natură văzută și nevăzută, adică înțeleasă cu mintea și simțită [trupește]... întrucât Dumnezeu este lumină înțeleasă cu mintea și Soare al dreptății $[$ Mal 4, 2] şi Răsărit [Zah 3, 8; 6, 12 LXX; Lc 1, 78] este numit în Scripturi Hristos, trebuie afirosit lui răsăritul spre închinare... Mai zice Scriptura: Sădit-a Dumnezeu rai în Eden, către răsărit, și 1-a pus acolo pe om, pe care 1-a zidit $[F c 2,8]$, pe care, călcând el porunca, l-a surghiunit din raiul desfătării și 1-a sălăşluit pe el dimpotriva raiului desfătării, adică la apus. Deci [tocmai] căutând vechea baștină și către aceasta ațintindu-ne privirile ne închinăm lui Dumnezeu. Și cortul cel mosaicesc spre răsărit avea catapeteasma și locul răscumpărării. Și seminţia iudei, ca una ce era mai de cinste, făcea tabără spre răsărit. Și în templul cel vechi al lui Solomon poarta Domnului spre răsărit era așezată’’’

Argumentul pus în lumină de Lang conține o structură interesantă pentru subiectul temei noastre: nu numai că accentul cade pe rugăciunea făcută spre răsărit, ci sunt menționate și etapele dezvoltării cultului liturgic: căutarea „vechii baștine”, a Edenului pierdut conduce către ceea ce Ioan Damaschin numește „,cortul mosaicesc", cu catapeteasma orientată din nou către răsărit, pentru ca, mai târziu și, desigur, corect din punct de vedere istoric, să se vorbească de o altă evoluție, permisă de contextul istoric în care sau desfășurat evenimentele, ajungându-se la Templul lui Solomon, orientat din nou către răsărit.

${ }^{9}$ Cf. Uwe Michael Lang, Privind către Dumnezeul nostru. Orientarea în timpul rugăciunii liturgice, trad. Mihail Khalid Qaramah și Mihai Răducă, București, Edit. Paralela 45, 2019, p. 77-78. 
Și aici, ca şi în cazul lui Torrance, există un precedent. $\mathrm{Cu}$ mult timp înainte de Lang, Sabino Moscati prezenta ceea ce numea „un element nou în concepția despre sanctuar" ${ }^{10}$. De fapt, Moscati, fără a se raporta la ideile și la planul din De fide Orthodoxa, arată că ,sanctuarul nu este numai, și în primul rând, templul: o largă răspândire o capătă sanctuarul în aer liber, situat lângă arbori și izvoare și mai ales pe înălțimi, așa cum se pomenește în Biblie. Sanctuarul în aer liber este format dintr-o imprejmuire și un altar, sau mai multe pietre sacre, în care se consideră că sălășluiește divinitatea locală" ${ }^{11}$. Din textele lui Ioan Damaschin și ale lui Moscati reiese că suntem în fața unei imagini duble: cea a locului de rugăciune (întotdeauna răsăritul) și cea, intrinsec legată de prima, a spațiului în care se va dezvolta templul ca edificiu. Alte aspecte au aceeași importanță: situarea altarelor „pe înălțimi” și forma pe care trebuie să o aibă: altarul, căruia i se adaugă o împrejmuire ne conduce spre biserica creștină, fie ea catedrală sau simplă capelă, în care, în preajma altarului se află acel ,perete cu icoane”, catapeteasma.

Mai departe, doresc să îmi concentrez cercetarea asupra importanței pe care o va avea imaginea templului iudaic, pentru că se va dovedi importantă în ceea ce privește argumentația pe care doresc să o construiesc pornind de aici. Și de această dată, simbolismul este puternic; după cum vom observa, simbolistica templului îmi va oferi bazele pentru validarea ipotezelor pe care le avansez. Punctul de sprijin, și de această dată, este un studiu amplu, dedicat în exclusivitate templului. Întocmit de Ronald E. Clements, volumul cu pricina, intitulat Dumnezeu și templul. Ideea de prezență divină în vechiul Israel, arată, printre altele, un aspect capital pentru ceea ce mă interesează, anume că ,templul și obiectele sale de cult au un simbolism cosmic, sau naturalist"12. Importantă este și critica adusă de Clements lui R. de Vaux, care

10 Sabino Moscati, Vechile civilizații semite, trad. Eugen Costescu, București, Edit. Meridiane, 1975, p. 122.

${ }^{11}$ Ibidem.

12 Ronald E. CLEMENTS, Dumnezeu și templul. Ideea de prezență divină în vechiul Israel, trad. Ilie Iuliana, Alba Iulia, Edit. Reîntregirea, 2015, p. 112. 
„,negase faptul că simbolismul templului ar avea o semnificație pentru Israel, și susține că acesta era doar o simplă consecință a implicării meseriașilor și arhitecților fenicieni"13.

Argumentația lui Clements se sprijină pe faptul că „,ideea fundamentală a fost aceea că templul era un microcosmos și un macrocosmos, astfel încât construcția oferea o expresie vizuală (subliniere mea) a credinței în suveranitatea lui Yahwe peste lume și peste forțele naturale... Simbolismul locașului sfânt era în relație cu semnificația și funcția cultului, astfel încât ritualurile prin care Israel s-a apropiat de Dumnezeu aveau și ca direcție esențială reprezentații adecvate a ordinii naturale"14.

Din cele referitoare la templu pe care le expune Clements, importantă este percepția templului ca ,expresie vizuală a credinței”. După cum voi argumenta mai departe, cuvintele de mai sus au o însemnătate mult mai mare decât cea care este sesizabilă la prima vedere. Aminteam mai sus de remarcabila imagine a templului. Dintre erudiții care au scris despre subiect, îmi reține atenția un studiu important, scris în tandem de regretatul cardinal Tomaš Špidlik şi de preotul Marko Ivan Rupnik. În volumul intitulat „Credință și icoană”, cei doi prezintă aspecte referitoare la iconografia marilor sărbători. În ceea ce privește sărbătoarea Intrării în Templu cei doi afirmă că templul avea mai multe funcții, arătând, de pildă, atât „locuirea lui Dumnezeu printre oameni" "15, cât și faptul că edificiul era „locul ales de Dumnezeu însuși, loc al harului, unde în timpul sfințirii a apărut slava lui YHWH sub forma unui nor care a umplut sanctuarul (cf. III $\operatorname{Rg} 8$, 10-11). Aici se venea din toate părțile lumii în pelerinaj pentru a căuta chipul lui Dumnezeu (cf. Ps 42, 3)"'16.

Toate cele de mai sus denotă, chiar dacă nu la fel de explicit ca Lossky și Uspensky ${ }^{17}$, că toate aspectele veterotestamentare

${ }^{13}$ Ibidem, p. 112, nota 192.

${ }^{14}$ Ibidem, p. 113.

15 Tomaš ŠPIDLIK, Marko Ivan RuPNIK, Credință şi icoană, trad. Ioan Milea, ClujNapoca, Edit. Dacia, 2008, p. 107.

${ }^{16}$ Ibidem, p. 107.

${ }^{17}$ Fac referire la volumul acestora, intitulat Călăuziri în lumea icoanei. 
legate de templu ,în iconografie [...] capătă o semnificaţie marială"'18. Ce înseamnă, deci această așa-numită semnificație marială? Ca să argumentez mai bine imaginea pe care îmi propun să o dezvolt, voi face mai întâi referire la cea de-a doua lucrare importantă, după cea a lui Torrance, care ne descoperă semnificația ortodoxă a ,întoarcerii din exil". Aici este vorba despre un alt mod de a imagina spațiul sacru, prin raportarea sa la ideea care desemnează un loc al penitenței. O perioadă liturgică din viața Bisericii Ortodoxe, numită ,perioada triodului”, care, temporal, ,se întinde" de-a lungul a zece săptămâni, premergătoare Învierii lui Hristos, descoperă sensul penitenței, al metanoiei în aşa-numita „duminică a lăsatului sec de brânză”, care mai este cunoscută ca „duminica izgonirii lui Adam din Rai”.

În cultura teologică autohtonă a fost tradusă cu ceva timp în urmă teza doctorală a unui ieromonah din Muntele Athos, de la mănăstirea Simonospetra, Makarios (Simonpetritul), intitulată sugestiv „Triodul explicat” ${ }^{19}$. Privitor la duminica menţionată mai sus, teza părintelui Makarios este aceea că ,tema izgonirii lui Adam din rai, legată de Duminica Lăsatului sec de brânză, reprezintă o transpunere a expulzării penitenților în afara bisericii, care odinioară avea loc atunci. Aceștia trebuiau să rămână în afara ușilor bisericii, icoană a raiului, și să-și plângă păcatele, pentru a fi reintroduşi în ea împreună cu catehumenii"20. Argumentul pe care se sprijină părintele Makarios a cunoscut anumite ecouri la noi, cu multă vreme înainte de apariţia acestei importante teze doctorale. De pildă, Alexandru Horia, în 1995, definea scoaterea penitențior din rândurile credincioșilor ca fiind o ,teologie de prispă (id est pridvor)” pentru că ,,prispa nu intră sub incidența teologiei, fiind considerată un element exterior spațiului ecleziastic... și, totuși, plasată la intrare, prispa este uvertura marelui scenariu creștin care se desfăşoară în Casa Domnului" ${ }^{21}$.

18 Tomaš ŠPIDLIK, Marko Ivan RUPNIK, op. cit., p. 107.

19 Cf. Ieromonah Makarios SimonPetritul, Triodul explicat. Mistagogia timpului liturgic, trad. Ioan I. Ică jr., Sibiu, Edit. Deisis, ${ }^{2} 2008$, 560p.

${ }^{20}$ Ibidem, p. 309.

${ }^{21}$ Alexandru HoRIA, Vorbirea în şoaptă, București, Edit. Anastasia, 1995, p. 12. 
Deci, pridvorul, ,acea lume exterioară” spaţiului eclezial, cu tot ceea ce se petrece aici, are o dublă importanță, de care voi vorbi în cele ce urmează, făcând pași spre conexiunile dintre aceste elemente cu gândirea lui Fotie. Observăm, prin urmare că, pe de o parte este vorba despre grija permanentă pe care o are Biserica pentru fiii săi și, pe de altă parte, în cuvintele mitropolitului Ioannis Zizioulas, această grijă este unită întotdeauna cu conceptul de metanoia:

„Fiind respins, sau prin simplul fapt că ne temem de el, celălalt ne provoacă și ne îndeamnă la pocăință... Pentru că toți împărtășim căderea lui Adam, trebuie să simțim mâhnirea de a nu fi reușit să aducem creația în comuniune cu Dumnezeu... Sfințenia în biserică trece printr-o stare de metanoia sinceră și adâncă... Prin accentuarea sfințeniei Bisericii, eclesiologia ortodoxă nu duce și nu trebuie să ducă la triumfalism, ci la un simțământ adânc de compasiune și de metanoia"22.

Toate cele enumerate mai sus, privite și analizate cu atenție, conduc spre o hermeneutică pe care, astăzi, se pare că teologia a înlăturat-o, dacă nu de tot, cel puțin parțial. Este vorba despre interpretarea transdisciplinară a unor texte aparținând teologilor bizantini, printre care se numără, desigur, și patriarhul Fotie.

Pentru că ideea principală a studiului se bazează pe interpretarea posibilă a unui tropar din Slujba aghiasmei mici, înainte de a prezenta semnificațiile iconice, geometrice și, implicit, arhitecturale ale acestuia, prezint textul cu pricina: „Acum a sosit vremea, care sfințește pe toți, și ne așteaptă Dreptul Judecător; ci te întoarce, suflete, către pocăință, ca păcătoasa care cu lacrimi striga: Doamne, miluiește-mă"23.

Paternitatea fotiană a acestui tropar nu reiese nici din edițiile moderne ale Molitfelnicului, nici din cele ale Aghiasmatarului. Însă,

${ }^{22}$ Ioannis ZIZIOULAS, Comuniune şi alteritate. Ființarea personal-eclesială, trad. Liviu Barbu, București, Edit. Sophia, 2013, p. 16-17.

${ }^{23}$ Cf. ***, Molitfelnic, București, Edit. Institutului Biblic şi de Misiune Ortodoxă, 2016, p. 191. 
de pildă, vechiul manual de liturgică al lui Badea Cireșeanu ${ }^{24}$, atribuie troparul menționat mai sus patriarhului Fotie. După cum arată cursul de teologie liturgică al părintelui Ene Braniște ${ }^{25}$, dar în armonie cu ceea ce ne interesează, atunci când sfințirea apei are loc în biserică, ea se oficiază în mijlocul naosului, cu fața către Altar. Aspectul este semnificativ, pentru că rânduiala actuală este perpetuarea obiceiului bizantin fotian. Și aceasta, pentru că, locul are o semnificație aparte: mijlocul naosului corespunde ca loc părții de sub cupola centrală, pe care este iconizat Hristos Pantocrator. Avem până acum, rezumativ, schița teologică următoare: limbaj și infăptuire (ceea ce descrie cu exactitate linia a ceea ce vrea imnograful să transmită), apoi altarul (cu dubla sa semnificație, de la Cortul Sfânt și Templul veterotestamentar, la semnificaţiile și simbolismul creștin, dar și penitențial), apa (ca element esențial al continuității manifestării binecuvântărilor divine) şi, desigur, culmea acestora Hristos Pantocrator (Dumnezeu Fiul, Care susține și menține întreaga creație).

Începusem studiul cu referirile la Templu și la simbolismul acestuia, totodată utilizând argumentele lui Moscati, care prezenta sanctuarele semite, așezate pe înălțimi, lângă arbori, neapărat împrejmuite, despre care se credea că reprezintă sălașul lui Dumnezeu printre oameni.

Tema va fi actualizată de studiul Arhiepiscopului Chrysostomos și al arhitectului și profesorului Augustin Ioan, în volumul pe care cei doi l-au intitulat Arhitectură în Biblie și la Sfinții Părinți ${ }^{26}$, unde se amintește de revelația primită de Moise: lui i-a fost revelată legea pentru cortul întâlnirii, deoarece

„totul va deveni real dacă (și numai dacă) va fi clădit întocmai, iar gestul constucției, prin tocmai actul revelării planului, va sacraliza - centru fiind - întreg situl de pe vârful

24 Badea Cireșeanu, Tezaurul liturgic al Sfintei Biserici Creștine Ortodoxe de Răsărit, tom. III, București, 1912, p. 344.

${ }^{25}$ Ene BRANIȘTE, Liturgica specială, București, Edit. Basilica, 2016, 655 p.

${ }^{26}$ Arhiepiscopul Chrysostomos, Augustin IoAn, Arhitectură în Biblie și la Sfinții Părinți, București, Edit. Pro Universitaria, 2013, 163 p. 
muntelui... Odată cu planul sunt furnizate și elemente de ritual adiacente, un adevărat manual cu instrucțiuni de folosire a templului, la fel de severe ca Leviticul, desfăcând în spirală reguli din chiar centrul care este planul cortului de întâlnire, anterior. Leviticul este continuarea în plan comunitar, social, a strictei alcătuiri a arhitecturii sacre; tot o zidire, în fond"27.

Consider valoroasă pentru ceea ce mă interesează în cercetarea pe care îmi propun să o realizez afirmația potrivit căreia „revelarea planului” este cea care ,sacralizează întreg situl". De aceste aspecte, dar în mod independent, firește, este conștient și teoreticianul și istoricul artei medievale, Erwin Panofsky care, vorbind totuşi despre arta medievală care s-a dezvoltat în Apus, nu de cea Răsăriteană, observă că ,toate cunoștințele omului medieval despre revelația divină și despre multe din celelalte lucruri pe care le considera adevărate îi erau transmise de autorități (auctoritates): în primul rând, de cărțile canonice ale Bibliei, care-i furnizau argumente intrinseci și irefutabile (proprie ex necesitate); în al doilea rând, de învățăturile Părinților Bisericii, care îi ofereau argumente intrinseci, dar doar probabile, și de filozofi, care îi livrau argumente extrinseci (extranea) și, implicit, doar probabile" 28 .

Sistemul gândit de Panofsky se bazează pe argumentele Bibliei. În cazul de față, de la templu se ajunge la simbolismul eclezial ortodox de origine bizantină. Și în această situație, textul Scripturii este singurul statornic; celelalte sunt doar elemente supuse probabilităților. Dacă Panofsky are dreptate, atunci Biblia este temelia opiniilor hermeneutice. Diferența între expresivităţile geometrice ale artei laice și arta eclezială constau în faptul că, atât arhitectura, cât și iconografia, deși cu variații interpretative, se sprijină pe acest text sacru. Aspectul este semnificativ. În arhitectura medievală, implicit în cea bizantină, cunoștințele

${ }^{27}$ Ibidem, p. 38.

${ }^{28}$ Erwin PANOFSKY, Arhitectură gotică și gândire scolastică, trad. Marina Vazaca, București, Edit. Anastasia, 1999, p. 82. 
trebuiau să fie diverse. O arată admirabila teză doctorală, întocmită de Simina Anamaria Purcaru, gândită pe marginea unui subiect foarte interesant, anume: Semiotica creației: poíēsis și poeta faber $^{29}$. După cum argumentează distinsa autoare, citându-l pe Filaret Averlino, arhitect, sculptor și teoretician al arhitecturii florentin, căruia i se datorează primul plan al unui oraș ideal al Renașterii, cultura arhitectului din orice perioadă trebuie să fie solidă. Iată ce cuvintele lui Averlino:

„Câte științe ar trebui să împărtășească arhitectul. Mai spune că trebuie să fie erudit, deoarece altfel nu poate ajunge un creator desăvârșit; și, în afară de aceasta, trebuie să cunoască arta desentului, trebuie să știe geometrie, astrologie, aritmetică, filosofie, muzică, retorică, medicină. Trebuie, de asemenea, să înțeleagă dreptul civil, deopotrivă trebuie să fie şi istoric; la toate aceste științe trebuie să fie părtaş, chiar dacă nu le știe perfect" $"$ 30.

Argumentele lui Averlino, capătă un sens aici dacă sunt raportate la cultura amplă a lui Fotie. Ceea ce vreau să demonstrez, ținând cont de toate cele expuse până acum, e că troparul forian pe care îl analizez nu este o creație întâmplătoare. A avut și ar trebui să aibă și acum un sens interdisciplinar: geometric, cosmologic și antropologic. Din cele enumerate reiese erudiția desăvârșită a autorului care, la vremea sa, deși nu era arhitect, ci ajunsese patriarh al capitalei Bizanţului, dar era și universitar de elită al vremii, a reușit să genereze o ,,arhitectură teologică”, rămasă prea puțin examinată minuţios, deoarece majoritatea studiilor care vizează personalitatea sa se axează pe polemica acestuia cu doctrina apuseană privitoare la adaosul din Crez, Filioque.

Dincolo de toate aceste polemici, Fotie are şi o altă importanță: punea în valoare știința vastă pe care o avea. HansGeorg Beck arată acest adevăr atunci când demonstrează că, după

29 Simina Anamaria PURCARU, Semiotica creației: poíesis și poeta faber, București, Edit. Paideia, 2019, 234 p.

${ }^{30}$ Ibidem, p. 78. 
cel de-al șaptelea Sinod Ecumenic din 787, s-a ivit momentul potrivit pentru ceea ce, în epocă, însemna o nouă preocupare: studierea cu acrivie a ,comorilor” adăpostite în biblioteca patriarhală din Constantinopol. Iată cuvintele lui Beck: „chiar dacă la început, doar din motive teologice se pare că și educaţia, care se dă la palat viitorilor înalți funcționari, joacă un anumit rol. Patriarhii Tarasie, Nichifor și Ioan Gramaticul, dar mai ales matematicianul Leon reprezintă începutul, Fotie şi Arethas primele culmi"’31. Mai departe, studiul lui Beck arată, de această dată doar în ceea ce-1 privește pe Fotie și pe Nechifor că deși ,au semnat de obicei ca patriarhi, importante aspecte din realizările lor literare le-au creat în calitatea de înalți demnitari imperiali - ambii au fost șefi ai cancelariei imperiale" 32 .

Faptul că Fotie era obișnuit cu ceea ce realizase la cancelaria imperială și, atunci când ocupase tronul patriarhal al Constantinopolului utiliza imagini care țin mai mult de administrație, decât de teologie, reiese, de exemplu, din scrisoarea pe care o trimite arhiepiscopului Aquileii, din nou, împotriva adaosului Filioque, în 883-884. Vorbind despre teologii apuseni, în speță despre episcopii Romei care au gândit și exprimat mărturisirea de credință fără adaosul Filioque, Fotie face apel la poziția teologică a lui Leon al IV-lea care, în cuvintele sale ,a predat celor din apus să slăvească şi să teologhisească Sfânta Treime [...] în graiul elin [...] și nu numai printr-un cuvânt și o poruncă, ci scriind-o pe nişte scuturi ca pe niște coloane și punându-le în ochii tuturor, le-a fixat pe porțile bisericii, ca să fie mai uşor și mai nefalsificat pentru toți să învețe buna cinstire de Dumnezeu și să nu mai existe de nicăieri vreo metodă de a falsifica buna-cinsire de Dumnezeu a noastră, a creștinilor, prin inserările ascunse ale unor cuvinte noi" ${ }^{33}$.

${ }^{31}$ Hans-Georg BECK, Mileniul bizantin, trad. Lidia Rus, București, Edit. Nemira, 2015 , p. 383.

32 Ibidem, p. 385.

${ }^{33}$ Cf. Ioan I. ICĂ jr, Canonul Ortodoxiei. Sinodul VII Ecumenic. Definind dogmatic orthodoxia, tom 2, Sibiu, Edit. Deisis, 2020, p. 539. Sublinierile din textul fotian citat îmi aparțin. 
Importantă este, și în situaţia de față, analogia dintre „scuturi” (imaginea oștirii), și „fixarea ca pe niște coloane”, însă ,pe ușile bisericii”. Suntem din nou în fața unui tablou variat, care pornește de la un element militar cu finalitate eclezială. Altfel spus, pentru Fotie, ecleziologia joacă un rol important, elementele mundane fiind oarecum contopite de harul prezent în biserică. Biserica este actualizarea templului iudaic. Dar, pentru că e vorba despre o bipolaritate, biserică și apă, propun să ne întoarcem din nou la textele veterotestamentare pentru a căuta precedente.

De pildă, în Cartea profetului Iezechiel, la cap. 47 se face aluzie la mai multe elemente care devin importante aici: din perspectivă geometrică, profetul vorbește despre poziționarea templului, colaborată cu existența unui ,râu care va da viață și care va curge din Templu" (Iezechiel 47, 1) ${ }^{34}$. Și la acest text profetic există un precedent: profeția lui Ioel care, în v. 1 din cap. 3 spune că Duhul Sfânt, ,în zilele de pe urmă” va fi ,,vărsat” peste tot trupul. Deși unii bibliști afirmă că, atât în situația lui Iezechiel, cât și în textul profetic al lui Ioel „este o referință doar simbolică a binecuvântărilor prezenței lui Dumnezeu, [...] nimic din pasaj nu indică faptul că Ezechiel nu s-a gândit la un râu literal. Detaliile, cum ar fi pescarii (v. 10), mlaștinile și gropile de pe mal (v. 11) dau o notă de realism acestui pasaj. Aceste detalii devin fără sens dacă pasajul doar simbolizează binecuvântările spirituale"35.

Troparul lui Fotie pe care îl analizez vorbește realmente despre „vremea” care „sfințește pe toți”. Textele profetice amintite vorbesc despre prezența reală a binecuvântării divine în apa care izvora din templu, prezență care se menține și se manifestă în apa sfințită din Biserica creștină. Dar, aici, consider că e necesară o întrebare: în ce măsură textele Scripturii 1-au influențat pe Fotie? Istoricul și bizantinologul Ionuț-Alexandru Tudorie arată în „Studiu Introductiv" din volumul care reunește textele patriarhului bizantin cu privire la „Mistagogia Duhului Sfânt” și la „Exegezele evangheliilor” că Fotie avea „calitățile unui teolog exersat” și că

${ }^{34}$ John F. WALvoord, Roy B. Zuck, op. cit., p. 1305.

${ }^{35}$ Ibidem. 
,atenția pe care a acordat-o textului biblic, în special Noului Testament, este reflectată în notițele sale care compun seriile

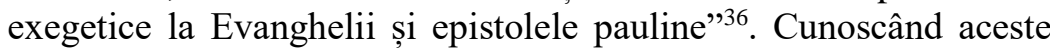
detalii, fie și numai schițate, e aproape sigur că Fotie s-a gândit la elemente biblice atunci când a alcătuit troparul Acum a sosit vremea...

De pildă, în acelaşi volum menționat, este inclusă o hermeneutică a Evangheliei după Luca în care, episodul cu femeia păcătoasă, care vine ,cu lacrimi” la Iisus, este descrisă astfel:

„Și mai trebuie să se știe că trei se arată a fi femeile despre care evangheliștii spun că L-au uns pe Domnul cu mir, și toate trei [au fost mânate] de multă credință și de o dorință înflăcărată: prima, cea de la Luca, a doua cea de la Ioan și a treia cea de la Matei și de la Marcu... Iar cea de la Luca unge picioarele cu mir, amestecând mirul cu lacrimile" ${ }^{\text {"37. }}$.

Troparul fotian poate fi înțeles și folosind o strucrură chiastică, după cum urmează:

A: Acum a sosit vremea, care sfințește pe toți

și ne așteaptă Dreptul Judecător;

B: ci, te întoarce, suflete, către pocăință,

B': ca păcătoasa care cu lacrimi striga: Doamne, miluiește-mă.

Din punct de vedere structural, vremea care sfințește pe toți depinde de întoarcerea fiecăruia, de metanoia. Însă Judecata cea dreaptă este mântuitoare, iarăşi, dacă cel care aude exemplul femeii păcătoase se pocăiește cu lacrimi, strigând: Doamne, miluiește-mă.

La toate cele enumerate, arta, împreună cu stilul arhitectonic oferă credinciosului, în biserică, o poziție privilegiată pentru a avea forța necesară de a se pocăi. Aici intervin câteva optici teologice,

${ }^{36}$ Cf. Ionuț-Alexandru TudoRIE, „De la elogii la invecctive și retur: itinerariul biografic al patriarhului Fotie", în Fotie Al Constantinopolului, Mistagogia Duhului Sfânt. Exegeze la Evanghelii, ediție bilingvă, trad. Oana Coman, Studiu introductiv și tabel cronologic de Ionuț-Alexandru Tudorie, note explicative de Oana Coman, Ionuț-Alexandru Tudorie și Adrian Muraru, Iași, Edit. Polirom, 2013, p. 59.

${ }^{37}$ Ibidem, p. 327-329. 
care ar putea să clarifice subiectul. Ceea ce eu am numit în paragraful anterior, generic, „forța credinciosului de a se pocăi”" conduce către o imagine care, până la a fi așezată corect și, implicit, până la integrarea ei într-un canon iconografic arată ca un tablou asupra căruia acționează diferite hermeneutici, toate justificându-se într-un fel sau altul. Ce mai înseamnă atunci conceptul de imago Dei de care, de exemplu, vorbește un teolog de calibrul lui van Huyssteen? Cum arată corect autorul, citând un text al lui Shults, ,apelul la Viitor în doctrina lui Dumnezeu se referă nu numai la nivelul temporal abstract pe care-1 numim «viitor», ci la viitorul absolut al domniei de pace a lui Dumnezeu, care a sosit deja sau este în curs de sosire şi va sosi, în cele din urmă, prin absoluta prezență a spiritului Cristos" 38. Așadar, imago Dei, după cum vorbește și Jürgen Moltmann, nu înseamnă doar că cea de-a doua Persoană a Sfintei Treimi S-a întrupat pentru a facilita îndumnezeirea, aşa cum este îndeobşte cunoscută afirmația și generalizată ci, mai mult înseamnă că, noi, chiar, dacă pornim de la mizeria păcatului uman, pentru a înțelege necesitatea împăcării dumnezeiești și pentru a aștepta venirea Împăciuitorului divin, trebuiesă depăşim măsura mizeriei umane, pentru a înțelege harul ca har al lui Dumnezeu"39. Or, cele două abordări sunt în consonanță cu optica lui Fotie asupra acelui timp penitențial. Orice „depăşire” (metanoia „corectă”, din perspectiva lui Moltmann), atrage harul simțit ca har al lui Dumnezeu. Iarăși, acestea înseamnă că, ceea ce argumentam mai sus, atunci când am folosit expresiile lui Shults, anume că viitorul şi temporalitatea ar putea însemna şi un spațiu imaginat, însă plin de prezența lui Hristos, ne arată că perspectiva fotiană bizantină se susține.

Mai mult, așa cum voi arăta în continuare, există un eveniment istoric major prin intermediul căruia gândirea fotiană s-a

38 J. Wentzel VAn HuISSTEEN, Singuri pe lume? Unicitatea omului în știință și în teologie [Conferințele Gifford. Universitatea din Edinburgh. Primăvara 2004], trad. Mihnea Gafița, București, Edit. Curtea Veche, 2015, p. 207, nota 15.

39 Jürgen Moltmann, Treimea şi Împărăția lui Dumnezeu. Contribuții la învățătura trinitară despre Dumnezeu, trad. Daniel Munteanu, Alba Iulia, Edit. Reîntregirea, 2007, p. 152. 
impus cu autoritate în Răsăritul ortodox. Apelez, din nou, la o autoritate în domeniu, pe care îmi sprijin afirmațiile, anume pe contribuția reputatului istoric Francis Dvornik care, într-un volum dedicat importanței culturii slavilor în istoria și civilizația europeană, afirma că există câteva evenimente care devin relevante pentru confirmarea ideilor pe care le susțin:

\begin{abstract}
„Astfel, de exemplu, în 1492, mitropolitul Zosima îl numea pe marele cneaz, în manieră bizantină «suveran și autocrat al întregii Rusii, noul împărat Constantin al noului oraș Constantinopol-Moscova». Învăţatul Ghenadie, arhiepiscop de Novgorod, a contribuit de asemenea la această evoluție. El făcea legătura între «țarul» Moscovei și împăratul bizantin și căuta probabil mai mult material în scrierile bizantine pentru propagarea acestor idei, deoarece în una din scrisorile sale cerea o copie a scrisorii lui Fotie către BorisMihail al Bulgariei, care era un fel de tratat de idei politice bizantine" ${ }^{, 40}$.
\end{abstract}

Toată această situație de mai sus a luat naștere și s-a diversificat datorită, în special, misiunii a doi celebri călugări, elevi ai lui Fotie, Chiril și Metodiu, cei care au convertit slavii la creștinism. Situația este admirabil prezentată de Charles Delvoye, eruditul care afirmase că

„numai Constantinopolul rămăsese singurul oraş cu adevărat prestigios care, unor popoare noi și îndeajuns de înaintate în istoria lor pentru a aspira la condiții superioare de existență, le propunea modelul cel mai desăvârşit de organizare politică, formele de artă cele mai rafinate, eticheta cea mai fastuoasă în celebrarea ceremoniilor religioase sau laice. Niciodată el nu a exercitat asupra lumii un atât de puternic ascendent ca în această epocă. Această fascinație a Bizanțului

${ }^{40}$ Francis DvorNIK, Slavii în istoria și civilizația europeană, trad. Diana Stanciu, București, Edit. All, 2001, p. 329. 
explică reușita lui în opera de creștinare a slavilor, întreprinsă începând din 863 de către Chiril și Metodiu, la inițiativa împăratului Mihail al III-lea și a patriarhului Fotie... În 864, hanul bulgarilor, Boris I (852-889) a venit să se boteze la Constantinopol şi a luat numele nașului său, împăratul Mihail al III-lea; el capătă titlul - până atunci rezervat rudelor basileului de Cezar, care a devenit în limba slavă «țar». La întoarcerea sa, a convertit în masă întreg poporul și și-a înzestrat capitala, Pliska, cu biserici imitate după cele din lumea bizantină" ${ }^{41}$.

Faptul că influența Constantinopolului, nu numai în politică și administrație, ci și în viața creștinilor ortodocși slavi a cunoscut o răspândire pe scară largă, se observă și în iconografie. Afirmația profesorului şi arhitectului Augustin Ioan, potrivit căruia, pentru expresivitatea misticului sau a tainei în Ortodoxie este necesar iconostasul, adică acel ,perete cu icoane”, care separă credincioșii de clericii din altar, este corectă. În cuvintele sale, iconostasul

„,introduce o piedică în plus împotriva accederii prea facile la un mister care trebuie să rămână inaccesibil, ultim. A-1 cunoaște, implică desacralizare... «Ochiul» (adică lumina) și «vederea» (receptarea ei) trebuie să întâlnească obstacole, pentru a se întoarce înăuntrul lor. Altarul închis spațial și aflat în semiîntuneric apropie/exaltă pe enoriași către Pantocratorul din centrul bolții/cupolei. Așa, după Sfânta Tradiție și icoanele sunt trepte ale unei posibile ascensiuni, intermediari de neînlocuit" ${ }^{\prime 2}$.

În privința legăturii dintre iconografie, geometrie și troparul fotian, cred că ipoteza pe care o susțin este plauzibilă pentru că

41 Charles Delvoye, Arta bizantină, vol. II, trad. Florica-Eugenia Condurachi, București, Edit. Meridiane, 1976, p. 9.

${ }^{42}$ Augustin IoAN, Introducerea în spațiul sacru, București, Edit. Paideia, 2004, p. 74. 
argumentele istorice și teologice sunt favorabile unei astfel de interpretări. Deci, dacă e adevărat că influența Constantinopolului a cunoscut o răspândire nemaiîntâlnită în lumea slavă, atunci modelul de iconostas rusesc, de care vorbesc studiile lui Lossky și Uspensky, reprezintă modelul standard pe care 1-au preluat celelalte popoare convertite. Preluarea nu a fost nici nouă, nici solitară, ci a fost un eveniment firesc al epocii. Studiul dedicat de arhitecta Silvia Păun fenomenului, pentru a oferi doar un exemplu, intitulat Absida altarului, vorbește despre basilica creștină „,are devine, încă din secolul al IV-lea, monumentul reprezentativ al cetătii, cum este situația și în Dacia Pontică, absida își sporește calitatea de componentă definitorie a expresiei arhitecturale, atât a volumului exterior, cât și a celui interior" ${ }^{\prime 3}$.

Cele menționate mai sus ar fi incomplete dacă nu am introduce și alte informații cu privire la simbolismul cosmic al bisericilor ortodoxe. Smaranda Maria Bica, de exemplu, atunci când prezintă simbolismul bisericilor ortodoxe, afirmă că altarul, orientat spre răsărit e imaginea raiului și, din acest motiv, ușile împărătești se numesc „Ușile Raiului”"44. Ceea ce m-a făcut să iau în calcul informațiile din teza doctorală a Smarandei Bica este faptul că vorbește despre centrul bisericii, loc în care se săvârșea, printre altele și rânduiala fotiană a Aghiasmei, centru care e simbol al pământului, după cum afirmă Cosma Inikopleustes ${ }^{45}$. Interesant: Cosma Indikopleustes, un negustor și călător din secolul al VI-lea, este și autorul unei opere intitulată în grecește Christianike Topografia, iar în limba latină, Topographia Christiana. Într-o imagine din acest manuscris, pământul este perceput sub forma unui paralelogram ca în imaginea de mai jos, preluată din varianta digitală a manuscrisului respectiv.

43 Silvia PĂUn, Absida altarului. L' abside de l'autel, traduit en français, prof.

Olimpia Coroamă, București, Edit. Per Omnes Artes, 2000, p. 170.

44 Smaranda Maria BICA, Cer=Cupolă (structura bisericii creștine), București, Edit. Paideia, 2000, p. 56.

${ }^{45}$ Ibidem. 

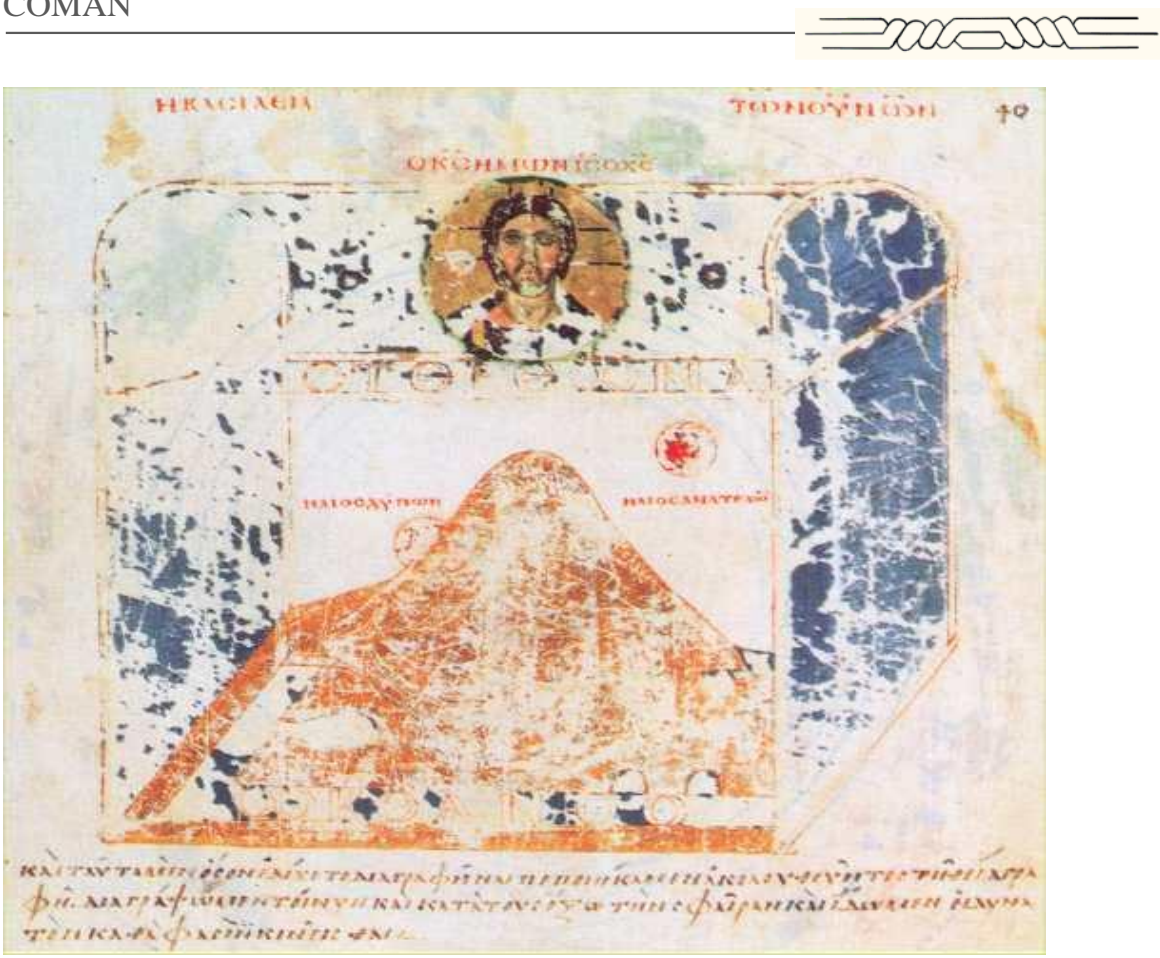

Avem, așadar, chipul lui Hristos, cu aproximație ca în icoana Hristos Pantocrator, plutind oarecum deasupra pământului întreg pe care pare să îl domine, imagine a pământului care, poate deloc întâmplător față de cele pe care le-am afirmat până acum este realizată sub forma unui munte. Dar, nu doar despre acest aspect este vorba aici: Fotie, în lucrarea devenită celebră, intitulată Biblioteca, destinată fratelui său, Tarasie, face aluzie și la lucrarea lui Cosma pe care o citise. Desigur că, în epocă, fiind o lucrare importantă, Fotie se va lăsa influențat de ea în ceea ce privește argumentele percepției asupra întregului pământ locuit. Smaranda Bica arată că în concepția lui Cosma,,pământul este dreptunghiular şi mărginit de patru ziduri care susțin bolta. Cele patru părți ale interiorului bisericii simbolizează așadar punctele cardinale" ${ }^{46}$. 
Așadar, revenind la importanța geometrică a ideilor teologice din troparul lui Fotie, dacă putem avansa certitudinea că modelul bizantin al arhitecturii eclesiale, cu tot ce a însemnat aceasta, s-a transmis în forma constantinopolitană bizantină și în lumea slavă, atunci forma iconostasului, care în argumentația ce va urma va juca un rol important, se va dovedi utilă pentru noile idei din final, pe care le-aș dori amplificate în viitoare studii tematice.

Deocamdată, modelul despre care doresc să vorbesc este cel rusesc, clasic, cunoscut prin intermediul studiilor lui Lossky și Uspensky, autorităţi în domeniu.

În studiul pe care 1-au dedicat icoanelor, cei doi teologi ruși prezintă un tip de iconostas care, de obicei, este întâlnit în bisericile rusești. $\mathrm{Nu}$ voi căuta să explic diferențele dintre modelele standardizate și cele care, din varii motive, cu influențe diferite, uneori venite, paradoxal, din lumea occidentală, diferă de modelul stabilit aici. Mă voi referi la acesta, presupunând utilizarea lui în creștinismul ortodox slav din cele mai vechi timpuri.

Modelul, după cum se poate observa din imaginea de mai jos, are icoanele așezate în registre care sunt cunoscute tuturor, cu mici diferențe. Nu face obiectul acestui studiu să vorbesc despre ele, însă voi prezenta ceea ce mă interesează, concentrând erminia pe care o propun pentru conexiune cu troparul fotian doar pe partea centrală, încadrată de „ușile împărătești”, cu icoana „Deisis” deasupra și, apoi, iarăși, important, cu registrul notat aici cu nr. 11, icoane cu praznicele împărătești, adică cu cele douăsprezece sărbători legate de Persoana lui Hristos sau de Maica Domnului.

Ipoteza mea ia în calcul următoarele aspecte: Fotie s-a gândit cu siguranță la impactul deosebit pe care îl aveau imaginile pentru credinciosul constantinopolitan. Perioada imediat următoare iconoclasmului garantează această perspectivă pe care o presupun. Din acel moment, credinciosul care va fi participat la oficierea sfințirii apei după rânduiala patriarhului, orientat cu fața către răsărit, va cunoaște că, prin ușile împărătești, dacă va fi cu luare aminte la cele ce se rostesc, are accesul simbolic în Impărăția lui Hristos, în Raiul pe care Adam 1-a pierdut. 


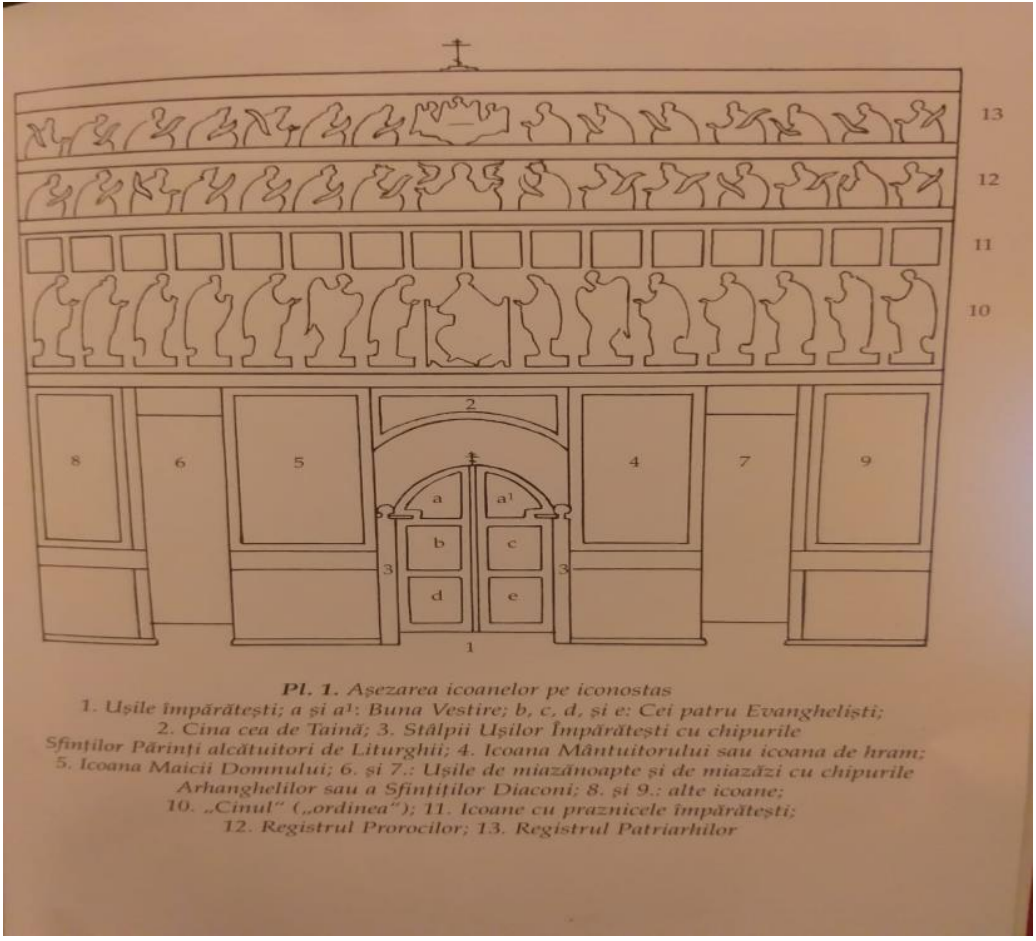

„Vremea care sfințește pe toți” este garantată vocal de utilizarea expresiei ,acum a sosit”, iar din perspectivă vizuală, se împlinește prin aceea că sufletul și trupul, indisolubil legate unul de altul, privesc Împărăția prin porțile impărătești, pe unde vor intra când Domnul va rândui, dacă și numai dacă vor fi participat cu pocăință $(\mu \varepsilon \tau o ́ v o l \alpha)$ și cu dedicare la Sfânta Liturghie, prin împărtăşirea cu Trupul și Sângele lui Hristos, care au redeschis Raiul. Mai mult, deasupra acestor uși centrale e aşezată, longitudinal, icoana cu Cina cea de Taină. Deasupra, Deisis, Hristos, Dreptul Judecător. Să ne oprim la aceste imagini și să le raportăm la textul Scripturii.

Voi apela pentru argumentare la exemplul neotestamentar, din Evanghelia după Ioan, unde, după cum arată Rinaldo Fabris, în ultima parte a capitolului 12, ,misiunea istorică a lui lisus este pe 
punctul de a se încheia"47. Din punct de vedere al importanței timpului, Fabris arată că ,puținul timp este valabil și pentru situația discipolilor, care trăiesc în perspectiva Paștelui, marcată de o nouă prezență a lui Iisus"

Acestea denotă faptul că ideea de timp care sosește în proximitatea lui Hristos trebuie valorificată printr-un efort ascetic susținut. De aceea, în privința afirmațiilor ioaneice, „ceea ce contează este faptul de a umbla atâta timp cât există lumina, sau «a umbla în lumină» pentru a deveni «fiii luminii», adică cei care aderă și participă în totalitate la realitatea mântuitoare a luminii" "49. Concluzia lui Fabris este aceea că „în contextul sfântului Ioan” conflictul lumină vs întuneric este „un limbaj cu nuanţă dualistă, specific pentru parenetica baptismală creștină"; din acest motiv „ultima notă redacțională contextualizează acest apel la alegerea luminii, cât mai este timp" 50 .

Din cele de mai sus este clar că e posibilă o analogie cu imnografia fotiană. E greu de spus dacă Fotie se gândea cu exactitate la cuvintele din Evanghelia după Ioan, dar e posibil să o fi făcut datorită simbolismului baptismal și datorită prezenței luminii răsăritului cu rol crucial în mântuirea omului.

Însă, textul ioaneic poate fi colaborat cu cel isaianic pe care, de fapt, evanghelistul Ioan îl citează: „Doamne, cine a crezut în ceea ce a auzit de la noi și cui i s-a descoperit brațul Domnului?" (Ioan 12, 38; Isaia 53, 1). Am citat textul acesta deoarece, după cum rezultă din ediția în limba română a Jerome Bible Commentary, pe care am utilizat-o, important este că, în textul ebraic, autorul cărții Trito-Isaia, cum este cunoscută în literatura de specialitate, a utilizat o acțiune predominantă sub forma unei contemplații silențioase ${ }^{51}$.

${ }^{47}$ Rinaldo FABRIS, Evanghelia după Sfântul Ioan. Traducere şi comentariu, trad. Cristian Ungureanu, Iași, Edit. Sapientia, 2016, p. 545.

${ }^{48}$ Ibidem.

${ }^{49}$ Ibidem.

${ }^{50}$ Ibidem.

51 Raymond E. Brown, Joseph A. Fitzmyer, Roland E. Murphy (coord.), Introducere și comentariu la Sfânta Scriptură. Literatura profetică, vol. VI, trad. Dumitru Groșan, Târgu Lăpuș, Edit. Galaxia Gutenberg, 2009, p. 483. 
Mai mult și, firește, relevant pentru ceea ce mă interesează e faptul că se arată utilizarea frecventă a verbului ebraic $r \bar{a}^{\prime} \hat{a}$ (a vedea), cu implicații spirituale, nu militare ${ }^{52}$. Ceea ce vede credinciosul prezent în fața iconostasului este icoana acestui braț puternic revelat prin har și imagine.

Mai departe, icoana numită Deisis ocupă aceeași poziție centrală, definită și de troparul fotian ca aspect vizibil al lui Hristos, Dreptul Judecător, care „ne așteaptă”. Acţiunea este continuă, aidoma pocăinței manifestate de comunitatea credincioșilor.

Spuneam că e important capitolul 12 al Evangheliei după Ioan, tocmai pentru că judecata lui Hristos, în cuvintele Sale de dinaintea Cinei celei de Taină, va fi îndreptată asupra „stăpânitorului acestei lumi” care „va fi aruncat afară” (Ioan 12, 31). După cum arată din nou excelent comentariul lui Fabris, „drama se rezolvă prin anunțul judecăţii, krisis, lumii şi a conducătorului acestei lumi. Aceasta coincide, în valența sa pozitivă, cu ridicarea lui Isus pe cruce, unde El devine centrul gravitațional al întregii realități istorice și lumești"53.

Aici doresc să intervin pentru a vorbi de ideea de corporalitate, în speță de Trupul lui Hristos privit ca centru gravitațional al creației. Aceasta înseamnă, de exemplu, în cuvintele lui Urs von Balthasar, că ,de vreme ce întreaga viață a lui Isus, cu cuvintele și semnele Sale, tinde către acel ceas, iar ceasul ce «va veni» 《este» deja dintotdeauna, pentru că acest ceas determină anticipat sensul fiecărui pas către El, în acest ceas devine evident ce înseamnă mântuirea și judecata - ca iubire. Lumea este creată până în ultimul amănunt de Logos, care este lumină și viață" ${ }^{54}$. Deci, acest amănunt al creației devine un aspect relevant în privința imaginii pe care o are credinciosul în față în biserică. Dar, modul de transformare interioară a acestuia îl creionează cel mai bine după părerea mea Emanuele Coccia,

52 Ibidem, p. 485.

${ }^{53}$ Cf. Rinaldo FABRIS, op. cit., p. 555.

${ }^{54}$ Hans Urs von Balthasar, Slava lui Dumnezeu. O estetică teologică. Teologie: Noul Testament, vol. VII, trad. Maria-Magdalena Anghelescu, Târgu Lăpuș, Edit. Galaxia Gutenberg, 2020, p. 273. 
filozoful contemporan care afirmase că, ,orice formă și orice lucru care ajunge să existe în afara locului său devine imagine. Forma noastră, de exemplu, devine imagine atunci când e capabilă să existe dincolo de sufletul nostru și dincolo de corpul nostru, fără a deveni la rândul său un corp" "55". O nuanțează părintele Georges Florovsky, uşor diferit, atunci când, referindu-se la dublul concept de har și libertate, afirmă că ,sinergia aceasta se manifestă în toate etapele vieții spirituale: omul în totalitatea sa este dublu. El își păstrează întotdeauna libertatea de a fi în acord cu Duhul sau a dispreți darurile sale"56. Dar toate acestea pot fi observate în amănunt atunci când, de pildă, urmărim și o altă interpretare, cea a prințului Trubețkoi cel care, într-un eseu dedicat iconografiei zicea că „omul încetează să mai fie o persoană suficientă sieși, supunându-se arhitecturii generale a întregului. Iconografia ne oferă imaginea unei umanități viitoare, sobornicești, reintegrate plenar în Biserică"

Iată că, mai departe, imaginea forte a femeii păcătoase care cerea milă poate fi remarcată și redescoperită arhitectural. Dacă, de exemplu, icoanele pot fi gândite ca ,mediatoare între două tărâmuri” atunci, acea „femeie păcătoasă” reprezintă o adevărată provocare penitențială pe care Fotie o lansează celor care știu să privească realitatea spațiului eclezial cu discernământ.

Dacă, de pildă, îmi rotesc privirea în sensul acelor de ceasornic, voi observa că pornesc invers față de ceea ce menționează troparul, anume de la icoana Deisis, către ușile impărătești ca, mai apoi, să urc cu privirea, prin dreapta Deisis-ului, unde Lossky și Uspensky aşază, în conformitate cu tradiția iconografică bizantină, icoana Pogorârii lui Hristos la iad, ca să ajung iarăși cu privirea în partea superioară a icoanei Deisis, locul de unde am pornit. Fotie, se pare, și-a dat seama de acest aspect

55 Emanuele CocciA, Viața sensibilă, trad. Alex Cistelecan, Cluj-Napoca, Edit. Tact, 2012, p. 30.

${ }^{56}$ Georges Florovsky, Sensul ascezei creștine, trad. Vasile Manea, Cluj-Napoca, Edit. Patmos, 2009, p. 58.

${ }^{57}$ Evgheni N. TRuBEȚKOI, 3 eseuri despre icoană, în românește de Boris Buzilă, București, Edit. Anastasia, 1999, p. 27. 
deosebit de relevant. Acest aspect are mai multe implicaţii simbolice. Una dintre ele este, ca să folosesc cuvintele profesorului și arhitectului Florin Biciușcă faptul că cerul „nu se află doar deasupra noastră, ci este un plan legat intim de toate celelalte planuri; astfel, evenimentele cerești își găsesc imediata lor proiecție în planul pământului, dar și în toate celelalte planuri (orașul, casa), inclusiv cel sufletesc" 58 .

Afirmația lui Biciușcă rezonează cu cea a mult mai celebrului Alexandre Koyré. Filozoful și istoricul științei Koyré afirmase că, de pildă, din perspectivă geometrică,

„nimic nu este mai opus decât calitatea de a fi «drept» și de a fi «curb»; şi totuşi, în cercul infinit mare circumferința coincide cu tangenta și în cercul infinit mic, cu diametrul. Mai mult, în cele două cazuri centrul își pierde poziția determinantă, unică; el coincide cu circumferința; este nicăieri; sau pretutindeni... Un alt exemplu îl poate oferi cinemateca. $\mathrm{Nu}$ există noțiuni mai opuse decât mișcarea și repaosul. Un corp în mișcare nu se află niciodată în același loc; un corp în repaos nu se află niciodată în altă parte... Așadar, centrul lumii coincide cu circumferința; el este un centru metafizic și nicidecum fizic, și care nu aparține acestei lumi. Acest «centru» care coincide cu «circumferința»sa, adică este început și sfârșit, fundament și limită, «locul» care îl «conține», nu este nimic altceva decât Ființa Absolută a lui Dumnezeu"59.

Din cele enumerate mai sus, observăm că imaginea credinciosului care, în timp ce ascultă psalmodia, își orientează privirea către răsărit, se poate înscrie în acel dinamism al credinței, esențial pentru o reușită a efortului de schimbare a minții și, implicit, o actualizare în viața personală a principiilor simbolice spirituale, vizibile prin intermediul arhitecturii, geometriei și al iconografiei bizantine.

${ }^{58}$ Florin BICIUȘCĀ, Centrul lumii locuite, București, Edit. Paideia, 2000, p. 72.

59 Alexandre KoIRÉ, De la lumea închisă la universul infinit, trad. Vasile Tonoiu, București, Edit. Humanitas, 1997, p. 14-15. 
Să fi creat Fotie troparul Acum a sosit vremea... gândindu-se la implicațiile tiparelor iconografice în mentalul credinciosului? $\mathrm{Nu}$ putem ști niciodată. Ceea ce am încercat să realizez a fost o ipoteză, pe care am încercat să o verific prin raportarea la cele mai importante „voci” ale biblisticii și ale teologiei. Și dacă, totuși, semnele, după cum am văzut, conduc spre afirmarea veridicitătii ipotezei e cu atât mai bine. Înseamnă că, în cuvintele eruditului preot rus Pavel Florenski,

„atunci când se contemplă tabloul, ochiul privitorului parcurge succesiv acele trăsături caracteristice, reproduce în conștiința sa o imagine având deja durată, aceea a unei idei incandescente, în palpitație și care a devenit mult mai matură și mai compactă decât imaginea lucrului însuşi, căci aici momentele cele mai limpezi, observate în timpi diferiți, sunt redate în stare pură, condensate și nu mai solicită efortul fizic de eliminare a reziduurilor. Întocmai ca pe ruloul gravat al unui fonograf, mintea privitorului glisează printre liniile și inciziile imprimate, fiecare punct trezind în privitor vibrații pe măsură. Aceste vibrații alcătuiesc, de fapt, scopul operei de artă" ${ }^{60}$.

$\cos 80$

\section{Bibliografie}

\section{A. Izvoare}

1. *** Molitfelnic, București, Edit. Institutului Biblic şi de Misiune Ortodoxă, 2016.

\section{B. Literatură secundară}

2. BECK, Hans-Georg, Mileniul bizantin, trad. Lidia Rus, București, Edit. Nemira, 2015.

${ }^{60}$ Pavel FloRENSKI, Iconostasul, trad. Boris Buzilă, București, Edit. Anastasia, 2009, p. 177. 
3. BICIUȘCĂ, Florin Centrul lumii locuite, București, Edit. Paideia, 2000.

4. BICA, Smaranda Maria, Cer=Cupolă (structura bisericii creștine), București, Edit. Paideia, 2000.

5. BRANIȘTE, Ene, Liturgica specială, București, Edit. Basilica, 2016.

6. Brown, Raymond E./ FITZMYER, Joseph A./ MurPHY, Roland E. (coord.), Introducere şi comentariu la Sfânta Scriptură. Literatura profetică, vol. VI, trad. Dumitru Groșan, Târgu Lăpuş, Edit. Galaxia Gutenberg, 2009.

7. Chrysostomos, Arhiepiscopul/ IOAN, Augustin, Arhitectură în Biblie și la Sfinții Părinți, București, Edit. Pro Universitaria, 2013.

8. CireșeAnu, Dr. Badea, Tezaurul liturgic al Sfintei Biserici Creștine Ortodoxe de Răsărit, tom. III, București, 1912.

9. Clements, Ronald E., Dumnezeu și templul. Ideea de prezență divină în vechiul Israel, trad. Ilie Iuliana, Alba Iulia, Edit. Reîntregirea, 2015.

10. Coccia, Emanuele, Viața sensibilă, trad. Alex Cistelecan, ClujNapoca, Edit. Tact, 2012.

11. DelvoYe, Charles, Arta bizantină, vol. II, trad. Florica-Eugenia Condurachi, București, Edit. Meridiane, 1976.

12. DVORNIK, Francis, Slavii în istoria și civilizația europeană, trad. Diana Stanciu, București, Edit. All, 2001.

13. Dumitru, Mircea, Lumi ale gândirii. Zece eseuri logico-metafizice, cuvânt înainte de Andrei Pleșu, Iaşi, Edit. Polirom, 2019.

14. FABRIS, Rinaldo, Evanghelia după Sfântul Ioan. Traducere și comentariu, trad. Cristian Ungureanu, Iaşi, Edit. Sapientia, 2016.

15. FloRENSKI, Pavel, Iconostasul, trad. Boris Buzilă, București, Edit. Anastasia, 2009.

16. Florovsky, Georges, Sensul ascezei creștine, trad. Vasile Manea, Cluj-Napoca, Edit. Patmos, 2009.

17. ICĂ jr., Ioan I., Canonul Ortodoxiei. Sinodul VII Ecumenic. Definind dogmatic orthodoxia, tom 2, Sibiu, Edit. Deisis, 2020.

18. HoRIA, Alexandru, Vorbirea în șoaptă, București, Edit. Anastasia, 1995.

19. IOAN, Augustin, Introducerea în spațiul sacru, București, Edit. Paideia, 2004. 
20. KOIRÉ, Alexandre, De la lumea închisă la universul infinit, trad. Vasile Tonoiu, București, Edit. Humanitas, 1997.

21. LANG, Uwe Michael, Privind către Dumnezeul nostru. Orientarea in timpul rugăciunii liturgice, trad. Mihail Khalid Qaramah şi Mihai Răducă, București, Edit. Paralela 45, 2019.

22. MAKARIOS SIMONPETRITUL, Ieromonah, Triodul explicat. Mistagogia timpului liturgic, trad. Ioan I. Ică jr., Sibiu, Edit. Deisis, ${ }^{2} 2008$.

23. MoltmanN, Jürgen, Treimea și Împărăția lui Dumnezeu. Contribuții la învățătura trinitară despre Dumnezeu, trad. Daniel Munteanu, Alba Iulia, Edit. Reîntregirea, 2007.

24. Moscati, Sabino, Vechile civilizații semite, trad. Eugen Costescu, București, Edit. Meridiane, 1975.

25. PANOFSKY, Erwin, Arhitectură gotică și gândire scolastică, trad. Marina Vazaca, București, Edit. Anastasia, 1999.

26. PĂUN, Arh. Silvia, Absida altarului. L' abside de l'autel, traduit en français, prof. Olimpia Coroamă, București, Edit. Per Omnes Artes, 2000.

27. Purcaru, Simina Anamaria, Semiotica creației: poíesis şi poeta faber, București, Edit. Paideia, 2019.

28. Ross, Allen P., „Psalmii”, în: John F. Walvoord, Roy B. ZucK, Comentariu al Vechiului Testament. O expunere a Scripturilor făcută de profesorii de la Seminarul Teologic Dallas, trad. Octavian Verlan și Constantin Leontiuc, Edit. Fundației E.B.E., 2010, p. 874.

29. ŠPIDLIK, Tomaš/ Ivan RUPNIK, Marko, Credință și icoană, trad. Ioan Milea, Cluj-Napoca, Edit. Dacia, 2008.

30. Torrance, Alexis, Pocăința în Antichitatea târzie. Asceza la Părinții răsăriteni și organizarea vieții creștine (cca 400-650 d. $H r)$, trad. Dragoș Dâscă, Iaşi, Edit. Doxologia, 2014.

31. TRUBEȚKOI, Evgheni N., 3 eseuri despre icoană, în românește de Boris Buzilă, București, Edit. Anastasia, 1999.

32. TUDORIE, Ionuț-Alexandru, „De la elogii la invecctive și retur: itinerariul biografic al patriarhului Fotie", în: FOTIE AL Constantinopolului, Mistagogia Duhului Sfânt. Exegeze la Evanghelii, ediție bilingvă, trad. Oana Coman, Studiu introductiv și tabel cronologic de Ionuț-Alexandru Tudorie, note explicative 
de Oana Coman, Ionuț-Alexandru Tudorie și Adrian Muraru, Iași, Edit. Polirom, 2013.

33. VON BALTHASAR, Hans Urs, Slava lui Dumnezeu. O estetică teologică. Teologie: Noul Testament, vol. VII, trad. Maria-Magdalena Anghelescu, Târgu Lăpuș, Edit. Galaxia Gutenberg, 2020.

34. VAN HuISSTEEN, J. Wentzel, Singuri pe lume? Unicitatea omului în știință și în teologie [Conferințele Gifford. Universitatea din Edinburgh. Primăvara 2004], trad. Mihnea Gafița, București, Edit. Curtea Veche, 2015.

35. ZizIOUlas, Ioannis, Comuniune și alteritate. Ființarea personaleclesială, trad. Liviu Barbu, București, Edit. Sophia, 2013. 